\title{
FIRST RECORD OF THE INCIDENCE OF THE COCONUT MITE, ACERIA (ERIOPHYES) GUERRERONIS KEIFER IN NIGERIA
}

\section{By}

\author{
C.I. Aisagbonhi, ${ }^{1}$ R.V. Nair ${ }^{2}$ and K.O. Kolade ${ }^{1}$
}

\begin{abstract}
In continuation of the search for the causes of premature nutfall of coconut palms in Nigeria, samples of fresh fallen nuts were examined under the microscope. Coconut palms (Chowghot Dwarf green (Indian), Malayian Dwarf yellow and Malayian Dwarf orange were surveyed between May to August 2003. The button stage nuts and premature nuts that recently fell on the ground were picked and conveyed back to the laboratory. The perianth (calyx ends) of each nut were split opened and examined under the microscope for presence of mites. Aceria(Eriophyes)guerreronis population were assessed per nut. All three ecotypes examined were infested. Preliminary observations indicated a mean mite population of $187.94+17.92$ per nut sampled.Mealybugs (Pseudococcus sp) and some unidentified mites were also observed. The role of these mites in the incidence of premature nutfall of coconut palms is discussed in this paper.
\end{abstract}

1/ Entomology Division, Nigerian Institute for Oil Palm Research (NIFOR), Benin City 2 Plant Breeding Division, NIFOR, Benin City.

2/ 


\section{INTRODUCTION}

Acari Eriophyidae, Aceria guerreronis (Coconut mite) was first discovered as a major pest of coconut (Cocos nucifera) in 1960 in Mexico. Later it was widely noticed in several countries in south America and Carribean region.Three species of eriopyid mites have been found on Florida coconut palms (Keifer 1962a,c;1965). Keifer (1962a,c) described two species in 1962: Acritonotus denmarki Keifer and Amrinus coconuciferae (Keifer). A third species, Aceria guerreronis Keifer was described in 1965 from coconuts in Mexico (Keifer 1965) and confirmed in Florida in 1984 (Howard et al, 1990).

The coconut mite, A.guerreronis, damages floral bracts, and scars developing coconuts in West Africa, Brazil and throughout the Carribean region (Howard et al). Nair et al (2001) described the following symptoms of A.guerreronis attack. The mites suck the plant sap with their needle like mouth parts,living on the tender meristematic region covered by the perianth. The first symptom of mite attack is the appearance of enlongated white lines below the perianth. Within a short time these feeding marks appear as pale yellow triangular patches below the perianth and gradually turns brownish in colour. As the nut grows, the injury forms warting and longitudinal fissures on the nut surface. Severe infestation by the mite results in poor development of nuts with reduced kernel weight and poor quality of fibre. Infestation by the mite during early stage nut development results in excessive button shedding. Severe infestation results in 20-25\% reduction in Copra, along with reduction in fibre content.

\section{RESULTS}

This investigation was undertaken in continuation of the search for the causes of premature nutfall of coconut palms in Nigeria. Materials and Methods Different ecotypes of coconut palms (Chowghot dwarf green(Indian), Malaysian dwarf yellow and Malaysian dwarf red were surveyed. The button stage nuts and premature nuts that recently fell on the ground were picked and conveyed back to the laboratory. The perianth (calyx ends) of each nut were split opened into six portions and examined under the microscope at 400,160 or 63 magnification, for presence of mites. The mite population were assessed per nut. The total number of fallen nuts, number of intact immature nuts and number of infested intact nuts on the palm were also assessed with the aid of a binocular.

Identification of Mites: Specimens observed under power 400 magnification in the microscope were identified by comparison with photomicrographs of Aceria guerreronis illustrated in CPCRI Annual Report(2002). The predominant mite was thus identified as Aceria guerreronis Keifer. Microscopic Examination: Table 1 indicates the mean number of Aceria guerreronis encountered in seventeen coconut palms (1 nut/palm) between May to August 2003. The mites were mostly found in the calyx end of the nuts. All three ecotypes examined were infested. These preliminary results indicate that there was a mean mite population of $187.94+$ 17.92 per nut.

Table 1: Number of Aceria guerreronis Keifer recorded per nut sampled

Serial Number of

$\begin{array}{cc}\text { nuts/palm } & \text { No. of Mites } \\ 1 & 247 \\ 2 & 100 \\ 3 & 70 \\ 4 & 43 \\ 5 & 6 \\ 6 & 101 \\ 7 & 31 \\ 8 & 0 \\ 9 & 1207 \\ 10 & 108 \\ 11 & 1 \\ 12 & 8 \\ 13 & 0 \\ 14 & 13 \\ 15 & 500\end{array}$




$\begin{array}{lc}16 & 660 \\ 17 & 100 \\ & \\ \text { Total } & 3195 \\ \text { Mean } & 187.94 \\ \text { SD } & 321.406\end{array}$

Plate 1 indicates some fallen premature nuts with visible symptoms (pale brownishyellow triangular patches just below the perianth, which gradually turn brownish in colour). Plate 2 indicates intact nuts with symptoms of attack on one of the coconut palms sampled.

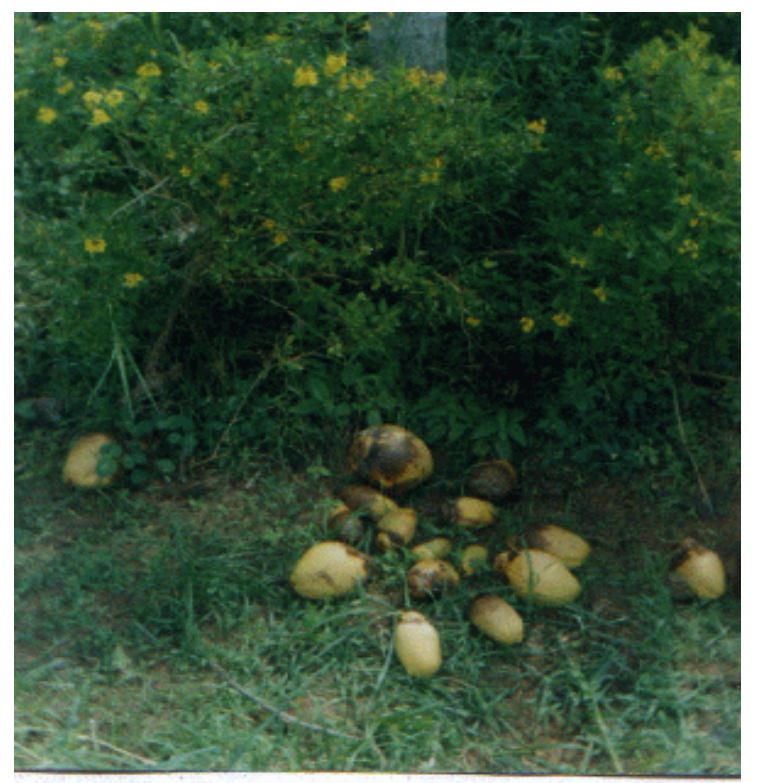

Plate 1. Fallen premature nuts with visible symptoms of mite attack (paleyellowish triangular patches).

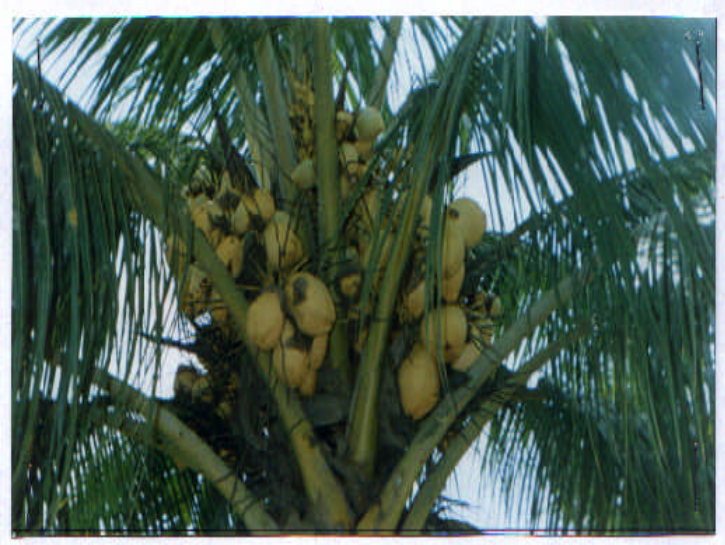

?late 2. Sume inlact nuts with symptoms of attack on one of the cocorul pelms sampled.

Plate 2. Some intact nuts with symptoms of attack on one of the coconut palms sampled.

Other unidentified mites of the family Tetranychidae and Pyemotidae, in addition to some Mealybugs (Pseudococcidae) were also observed. Some dead Aceria guerreronis were also observed during microscopic examination. Up to $67 \%$ mortality of the mite population in highly infested nuts was recorded.

\section{DISCUSSION}

The findings made during this investigation in which Eriophyid mites of the species Aceria guerreronis were observed damaging the perianth end of young immature nuts has helped expand our frontier of knowledge in Nigeria of the causative organisms known to be responsible for the incidence of premature nutfall. Though Howard et al 1990, reported that the coconut mite, A.guerreronis damages floral bracts and scars developing coconuts in West Africa,Brazil and throughout the Carribean region, including Mexico, Colombia, and Venezuela,the report made in this study is the first record of the occurence of the mite in Nigeria.Reports on the destructive effects of mites at Kayangulam, India, indicated that infestation by the mite during early stages of nut development results in excessive button shedding, 20-25\% reduction in copra and reduction in fibre content (CPRI, 2001) Findings 
made at CPRI, India, has indicated that there are some successes recorded in the use of the following measures for the Management of the pest. These measures can be adopted for the mite control in Nigeria.

There are possibilities for the biocontrol of the mite using predacious mites, insects and pathogenic fungus, like Hirsutella thompsoni. A mycoacaricide formulated from $\mathrm{H}$. thompsoni ("mycohit") has been found effective in providing up to $80 \%$ death of mite population depending on various environmental factors. Spraying of affected palms with a mixture of 2 percent neem oil, garlic and soap mixture has been found effective (Kumar \& Sign, 2003). 0.004 percent azadirachtin (a botanical) was found useful and gave a good control of the pest in the field, by spraying 1 percent azadirachtin at the rate of $4 \mathrm{ml}$ per litre of water.

Various chemical pesticides have also been found effective for mite management in studies undertaken at CPRI. Micronised wettable formulation of sulphur has given good control of the mite. Sulphur is recommended for spraying at $0.4 \%$ concentration ( $5 \mathrm{gm}$ per litre of water). $0.05 \%$ carbosulfan has also been found effective in management of the mite. The pesticides should be applied only on the perianth region of nuts to ensure its penetration into the perianth lobes and inner surface through capillary action. Before spraying, the mature bunches should be harvested, and care taken to avoid spraying unpollinated bunches.

This paper records the incidence of the coconut mite Aceria guerreronis in Nigeria. This is the first time it has been recorded in the country. However, further lines of investigation on the population dynamics of this pest covering 2-3 years collation of ecological data will help in the analysis of the key factors governing the occurrence and distribution of this pest in Nigeria.

\section{ACKNOWLEDGMENT}

We thank Dr. U. Omoti, Director, Nigerian Institute For Oil Palm Research, P.M.B. 1030, Benin City, for his support, interest and approval of this project. We also thank Dr. (Mrs) Okwuagwu for her support.

\section{REFERENCES}

Keifer, H.H. 1962a. Eriophyid studies B-6. Bureau of Entomology, California Department of Agriculture, Sacramento. 20p.

Keifer, H.H. 1962b. Eriophyid studies B-7. Bureau of Entomology, California Department of Agriculture, Sacramento. 20p.

Keifer, H.H. 1962c. Eriophyid studies b-8. Bureau of Entomology, California Department of Agriculture, Sacramento. 20p.

Keifer, H.H. 1965. Eriophyid studies B-14. Bureau of Entomology, California Department of Agriculture, Sacramento. 20p

Howard, F.W., Abreu-Rodriguez, E., and, H.A. Denmark. 1990. Geographical and seasonal distribution of the coconut mite, Aceria guerreronis (Acari:Eriophyidae), in Puerto Rico and Florida, USA Journal of the Agricultural University of Puerto Rico. 74: 237-251

CPCRI(2001)Central Plantation Crops Research Institute Research Institute Extension Publication Number:89(September,2001) Edited by C.P.R. Nair,Smt.Chandrika Mohan and Murali Gopal CPCRI(2002) Central Plantation Research Institute Annual Report (2002).

Kumar P Sreerama and S.P Singh (2003) Microbial Control of Coconut mite.The Hindu. 